\title{
Zooplankton community structure and dominant copepod population structure on the southern Kerguelen Plateau during summer 2016
}

\author{
Kohei Matsuno ${ }^{1,2,3}$, Jake R. Wallis ${ }^{3,4}$, So Kawaguchi ${ }^{3,5}$, Sophie Bestley ${ }^{4,6}$, Kerrie M. Swadling 3,4 \\ ${ }^{1}$ Graduate School of Fisheries Sciences, Hokkaido University \\ ${ }^{2}$ Arctic Research Center, Hokkaido University \\ ${ }^{3}$ Antarctic Climate \& Ecosystems Cooperative Research Centre \\ ${ }^{4}$ Institute for Marine and Antarctic Studies, University of Tasmania \\ ${ }^{5}$ Australian Antarctic Division \\ ${ }^{6}$ CSIRO Oceans and Atmosphere
}

The Kerguelen Plateau, and areas to the south, represents one of the most important regions for primary production in the Indian sector of the Southern Ocean (Arrigo et al., 2008), with high stocks of toothfish and krill found in the north and south, respectively (Nicol, 2006). However, the southern Kerguelen Plateau has never been investigated as a single region to determine the distribution and abundances of key species, their habitat characteristics, and the transition from the northern fishbased foodweb (Pruvost et al., 2005) to the southern krill-based foodweb (Nicol et al., 2012). This study was conducted as part of the Kerguelen Plateau (designated the KAxis cruise, 2016) study designed to examine details of the marine foodweb from bacteria to mid-trophic levels (fish and squid). A key aim of the cruise was to study the transition from the krill-based foodweb in the south to the copepod-fish based foodweb in the north. This component of the program focusses on the horizontal distribution of zooplankton over the top $200 \mathrm{~m}$, as collected by an RMT1 net. Population structure of dominant copepods is also presented. To evaluate the effects of environmental factors on zooplankton distribution we applied general linear modelling (GLM).

Zooplankton abundance ranged from 1,490 to 363,484 ind. $1000 \mathrm{~m}^{-3}$, with highest numbers observed in the eastern and central areas. Based on cluster analysis the zooplankton were divided into 6 groups (A-F) that were associated with water masses and frontal systems (Figure 1). Groups A to $\mathrm{C}$ had abundant zooplankton and were consistent with areas of high chlorophyll a concentration. Group D represented low abundance near the southern Antarctic Circumpolar Current front, while group E was clustered south of the Southern Boundary and group F comprised twostations to the east of the Fawn Trough. GLM highlighted both fronts and primary production as drivers of overall zooplankton distribution. This was not the case for drivers of population structure of key species, a result of species-specific life cycles.

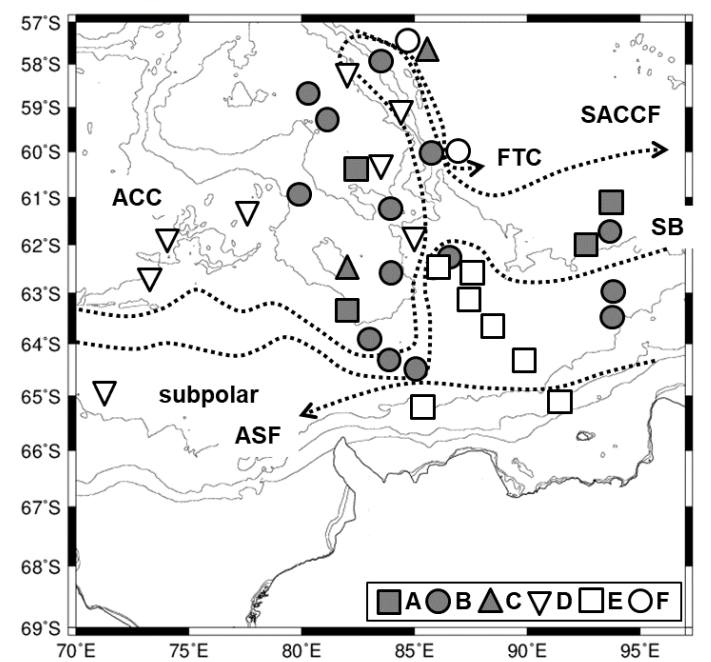

Figure 1. Station groupings along the Kerguelen Axis, as determined from cluster analysis and non-metric multidimensional scaling. Positions of frontal systems based on Bestley et al., 2018. ACC: Antarctic Circumpolar Current; ASF: Antarctic Slope Front; FTC: Fawn Trough Current; SB: Southern Boundary; SACCF:

\section{References}

Arrigo, K.R., Van Dijken, G.L. and S. Bushinsky, Primary production in the Southern Ocean, 1997-2006. Journal of Geophysical Research, 113, C08004, 2008.

Bestley, S., van Wijk, E., Rosenberg, M., Eriksen, R., Corney, S., Tattersall, K. and S. Rintoul, Ocean circulation and frontal structure near the southern Kerguelen Plateau: The physical context for the Kerguelen Axis ecosystem study. Deep-Sea Research II, https://doi.org/10.1016/j.dsr1012.2018.1007.1013, 2018.

Nicol, S., Krill, currents, and sea ice: Euphausia superba and its changing environment. BioScience, 56, 111-120, 2006.

Nicol, S., Foster, J. and S. Kawaguchi, The fishery for Antarctic krill recent developments. Fish and Fisheries, 13, 30-40, 2012.

Pruvost, P., Duhamel, G. and M.L.D. Palomares, An ecosystem model of the Kerguelen Islands' EEZ. In: Palomares, M.L.D., Pruvost, P., Pitcher, T.J. and D. Pauly, (eds.) Modeling Antarctic marine ecosystems.

Fisheries Centre Research Reports 13(7). Fisheries Centre, University of British Columbia, Vancouver, Canada, pp. 40-64, 2005. 